\title{
A SOCIOLOGIA DA RELIGIÃO COMO RECAPITULAÇÃO DA TEOLOGIA CRISTÃ Weber e as raízes proféticas do racionalismo ocidental
}

\section{Renan Springer de Freitas}

Em todos os tempos só tem havido um meio de quebrar o poder da magia e estabelecer um padrão racional de conduta; este meio é a grande profecia racional. WeBER (1993, p. 362)

Profecias liberaram o mundo da magia e, ao fazê-lo, criaram a base para a ciência e a tecnologia modernas, como também para o capitalismo.

WEBER (1993, p. 362)

Desde os escritos seminais de Max Weber, a sociologia da religião tem desenvolvido uma linha de raciocínio bastante curiosa a respeito do significado cultural e histórico da profecia hebraica. Por um lado, esta última tem sido vista como nada menos que o empreendimento intelectual que gerou a singularidade da nossa civilização ao conceber a idéia de um Deus universal (que re-

Artigo recebido em junho/2007 Aprovado em agosto/2007 compensa quem obedece a Seus mandamentos e pune quem os transgride) e estabelecer, a partir dessa concepção, o preceito, incompatível com "todo pensamento genuinamente asiático", de que "por meio de um comportamento prosaico, dirigido às 'demandas do dia', é possível obter salvação" (Weber, 1960, pp. 332, 342). ${ }^{1}$ Por outro lado, tem lhe sido atribuída a promessa de um futuro no qual Israel prevaleceria sobre todas as outras nações, a qual, após a devastadora experiência do exílio na Babilônia (século VI a.C.), teria transformado os judeus em um "povo-pária", auto-segregado, ressentido, ritualista, legalista, orientado por uma ética dual (isto é, com um padrão de comportamento em relação aos judeus e outro em relação aos gentios) e, como tal, incapaz de difundir o "padrão racional de conduta" que a doutrina profética de um Deus universal havia estabelecido. ${ }^{2}$ Essa linha de raciocínio conduziu à tese de que, se, por um lado, a doutrina profética hebraica anterior ao exílio desencadeou o processo 
de formação dos traços caracteristicamente "racionais" do padrão de conduta que se estabeleceu no ocidente, por outro, o fato de os judeus terem sobrevivido ao cativeiro apenas como um "povo pária", orientado por uma "ética dual", impediu a continuidade deste processo, o qual, não obstante, não foi interrompido para sempre por causa do subseqüente advento do universalismo cristão.

Essa postulada transição do particularismo judaico ao universalismo cristão encontra-se na base de todo esforço já realizado pela sociologia weberiana para explicar a emergência do racionalismo peculiar ao ocidente. A versão mais acabada desse esforço encontra-se na obra de Wolfgang Schluchter, que, mais do que ninguém, empenhou-se em argumentar que enquanto as escrituras judaicas instituíram o que poderia ser chamado de um "reino da legalidade", isto é, uma ética baseada na observância mecânica de normas concretas, o Novo Testamento, ao rechaçar o intelectualismo judaico, típico dos centros urbanos, ${ }^{3}$ realçando, no lugar, a importância da convicção supra-intelectual, instaurou o "reino da moralidade", isto é, uma ética baseada em princípios abstratos internalizados. ${ }^{4}$ Paulo é apontado como o grande arquiteto dessa transição, cuja caracterização o próprio Weber encarregou-se de fazer em termos muito vivos:

Com a ajuda de uma dialética que somente um rabino poderia ter, Paulo, por onde passou, erradicou o que era mais peculiar à lei judaica, como também o que era mais eficiente nela, a saber, as normas com caráter de tabu e as promessas messiânicas únicas. Posto que esses tabus e essas promessas vinculavam toda a dignidade religiosa dos judeus à sua condição de povo pária, a ruptura efetivada por Paulo foi fatal em seus efeitos. Paulo efetuou esta ruptura postulando que as promessas messiânicas presentes nas escrituras judaicas haviam sido parcialmente cumpridas, e parcialmente abolidas, pelo nascimento de Cristo. De uma forma triunfal ele usou o argumento, de fato impressionante, de que os patriarcas de Israel, já bem antes que os tabus e promessas judaicas fossem tornados públicos, haviam vivido de acordo com a vontade divina e, graças à sua fé, que era a garantia da eleição por Deus, alcançado a bem-aventurança. A força que impulsionou o trabalho incomparável da missão de Paulo foi sua oferta, aos judeus, de um tremendo alívio, um alívio proporcionado pela consciência de ter escapado ao destino de pária. O judeu, a partir de agora, poderia ser um heleno para os helenos do mesmo modo que um judeu para os judeus [...]. Esta foi a sensação apaixonada de liberdade trazida por Paulo. O judeu poderia realmente livrarse das antigas promessas de seu Deus colocando sua fé no novo salvador, que se sentiu abandonado na cruz por aquele mesmo Deus. Várias conseqüências se seguiram deste rompimento das cadeias vigorosas que mantinham os judeus firmemente presos à sua condição de pária. Uma delas é o ódio terrível, suficientemente documentado, precisamente dos judeus da diáspora contra este homem [...]. Em cada linha escrita por Paulo sentimos o júbilo contagiante de um homem que foi resgatado, com o sangue do Messias, da "escravidão" daquela lei sem esperança para a liberdade. A conseqüência mais ampla foi a possibilidade de uma missão cristã mundial (Weber, 1965 [1922], pp. 259-260).

Este longo excerto sugere que faltou às escrituras sagradas judaicas um alcance universal, ${ }^{5}$ isto é, que nenhuma "missão mundial" poderia ter sido iniciada a partir da pregação profética hebraica a menos que o padrão particularista de conduta peculiar ao judaísmo fosse rompido e substituído por um padrão universalista. Na medida em que, nos marcos dessa linha de raciocínio, o trabalho missionário de Paulo foi o acontecimento responsável por tal ruptura e substituição, ele significou uma guinada decisiva na evolução da ética ocidental.

Nesse artigo discuto a pertinência de toda essa linha de raciocínio. Argumento que ela se limita a recapitular uma concepção teológica oriunda do pensamento cristão do segundo século, a saber, a de que o sacrifício redentor de Jesus tornou o judaísmo obsoleto porque universalizou o acesso à graça divina anteriormente restrito a um suposto "povo escolhido". Embora esta concepção possa ser encontrada em escritos cristãos do primeiro século, sua forma mais acabada aparece na obra do apologista Justino, o mártir (100165), ${ }^{6}$ e é conhecida, desde o influente trabalho da teóloga cristã Rosemary Ruether, por teologia da superação - ou teologia da substituição (Ruether, 1974). Nessa perspectiva, pretendo mostrar o quanto o argumento weberiano a respeito da emergência do racionalismo ocidental se acha embebido na teologia cristã da superação. Ao atri- 
buir à ética farisaica, peculiar aos judeus da época da pregação Paulina, um caráter particularista, pré-Paulino, que em boa hora veio a ser substituído e superado pelo universalismo subjacente à doutrina Paulina da justificação pela fé, a sociologia da religião tem sido levada, por um lado, a subestimar o potencial universalizador do arcabouço religioso judaico e, por outro, a superestimar o papel histórico-cultural da doutrina Paulina da justificação pela fé: conforme pretendo mostrar, o desenvolvimento do cristianismo e, por extensão, do racionalismo ocidental, dependeu de fatores cuja conexão com a referida doutrina, e com o trabalho missionário de Paulo de um modo geral, é muito menor do que o pensamento weberiano nos levaria a supor.

\section{1}

No excerto acima Weber parafraseia, com grande admiração, o versículo da Epístola de Paulo aos Gálatas, que diz: "não pode haver judeu nem grego; nem escravo nem liberto; nem homem nem mulher; porque todos vós sois um em Cristo Jesus" (Gl 3:28). Weber parece supor que essas palavras traziam algo de substancialmente novo para os judeus ou gentios de língua grega a quem Paulo se dirigia. Tal suposição, entretanto, dificilmente se sustenta. Em um artigo recente, David Niremberg (2003) argumenta que o universalismo presente no versículo acima já era subscrito por um dualismo filosófico (freqüentemente chamado de neoplatônico) muito difundido, o qual chamava a atenção para a existência de uma irmandade de espírito e enfatizava a superioridade do estado espiritual sobre as várias diferenças de corpo e de circunstância que marcam a "carne" dos seres vivos. Nesse sentido, o que haveria de extraordinário no referido versículo seria o fato de Paulo ter defendido seu universalismo contra um status particular que era até então quase que inteiramente ignorado pela tradição filosófica grega. Nem a condição de homem ou mulher, nem a condição de liberto ou escravo, mas somente o judaísmo servia como o alvo permanente de sua eloqüência. Isto aponta para o fato de
[...] o universalismo de Paulo ter sido articulado no contexto e nos termos de uma luta pelo controle sobre o passado judaico. De todas as antinomias de identidade a partir das quais ele foi construído, foi somente a categoria de judeu, de descendente de Abraão - não as categorias de grego, escravo, mulher ou homem -, que precisava se expandir para abrir espaço para toda a humanidade (Niremberg, 2003, p. 210).

Essas considerações chamam a atenção para algo que escapou a Weber, a saber, que Paulo não negou as distinções homem/mulher e escravo/ liberto da mesma forma que negou a distinção judeu/grego. Nos dois primeiros casos, Paulo está dizendo que, embora a condição de homem ou mulher, escravo ou liberto, é irrelevante perante Deus sob um ponto de vista religioso e espiritual, cada homem, mulher, escravo ou liberto deve se manter como tal do ponto de vista físico e social. No caso da distinção judeu/grego, entretanto, tudo muda. Neste caso, como explicou muito bem o historiador da religião John D. Crossan, em seu The birth of Christianity, Paulo "tira a distinção da alma e a coloca no corpo; tira-a do espírito e a coloca na carne" (1999, p. xxv). Para entender este argumento, basta imaginar o que significaria negar as distinções homem/mulher e escravo/ liberto da mesma forma que Paulo negou a distinção judeu/grego. Significaria supor que seria indiferente perante Deus que, por exemplo, um homem pintasse as unhas ou inserisse silicone no peito, ou que um escravo se rebelasse contra a sua condição. Certamente não era nada disso que Paulo tinha em mente quando disse que não pode haver homem nem mulher, nem escravo nem liberto, perante Cristo. Mas era exatamente algo desta natureza que estava presente na sua negação da distinção judeu/grego. Nenhum homem, nem escravo algum poderiam, segundo Paulo, renunciar à sua condição física e/ou social (quer pintando as unhas, quer renunciando a servir a seu amo), mas um judeu poderia renunciar à sua condição físico-social abrindo mão das "normas com caráter de tabu" e das "promessas messiânicas únicas” contidas na Torá. Há, portanto, uma clara incoerência aqui, e o próprio Weber acabou por incorporá-la ao seu pensamento ao elogiar Paulo por oferecer aos judeus uma oportunidade (não aproveitada) para abandonar o judaísmo. ${ }^{7}$ 
Se Weber equivocou-se ao supor que o citado versículo Paulino trazia alguma novidade teologicamente revolucionária, ele, não obstante, estava certo ao dar a entender que a posição de Paulo era motivada pela tensão entre dois objetivos: o de manter a relevância da promessa de Deus a Abraão (e, portanto, a relevância das escrituras judaicas) e o de estender esta promessa para além dos descendentes carnais de Abraão. Afinal de contas, como Niremberg nos faz lembrar, se o objetivo de Paulo tivesse sido o de abandonar as escrituras sagradas dos judeus, ou de simplesmente condená-las como falsas - como pouco mais tarde o fariam tanto os marcionitas como os cristãos gnósticos, aos quais oportunamente retornarei -, "o particularismo judaico não teria se tornado mais importante para os primeiros cristãos do que todo um conjunto de outras identidades étnicas que eles foram capazes de simplesmente ignorar como espiritualmente insignificantes" (Niremberg, 2003, pp. 210-211). Mas, como Paulo não o fez, o caminho ficou aberto para que a "questão judaica" se tornasse o problema chave da hermenêutica cristã e na elaboração da teologia e ontologia cristãs.

Que a "questão judaica" tenha se tornado o problema chave da hermenêutica cristã é algo que dificilmente alguém contestaria em nossos dias. Na verdade, o próprio Weber parece estar sugerindo isso ao afirmar que uma das "atividades sem par" de Paulo, que teve "efeitos significativos para o cristianismo primitivo", foi ter "transformado o livro sagrado dos judeus em um dos livros sagrados dos cristãos e, no princípio, o único" (Weber, 1965 [1922], p. 259). Há de se perguntar, entretanto, se não seria mais apropriado ver tão extraordinário feito como a culminação de um processo muito mais complicado e laborioso, isto é, como o resultado final de uma longa e sangrenta batalha pela criação da ortodoxia cristã - ou, o que resulta no mesmo, como a solução que se obteve, após um enorme esforço, para um problema extremamente espinhoso que, por muito boas razões, dominou todo o período patrístico. Refiro-me ao problema, jamais abordado por Weber, ou por seus seguidores, de saber se o Deus dos judeus e o dos cristãos era o mesmo.

É sabido que nas décadas que se seguiram à crucificação de Jesus muitos caminhos alternati- vos estavam abertos para o que posteriormente viria a ser chamado de cristianismo. ${ }^{8}$ Quando Paulo iniciou seu trabalho missionário, em meados do primeiro século, um leque de "cristianismos" potencialmente viáveis já estava se formando, e o cristianismo que ele próprio lutou para estabelecer era apenas um a mais. Weber, evidentemente, estava ciente disto. Ele parece não ter estado suficientemente atento, entretanto, para uma outra coisa, a saber, que qualquer que fosse a forma final a ser tomada pelo cristianismo, o caminho que conduziria a ela seria atravessado por uma questão absolutamente decisiva: o que fazer do Deus da Bíblia hebraica? - o deus da vingança e da espada, como o diria o teólogo patrístico Marcião (85-159), cujo pensamento só nos é acessível pelos escritos de seus inúmeros adversários. Poderia o Deus ciumento e punitivo dos judeus ser reconciliado com o Deus do amor e da compaixão, dos (então emergentes) cristãos?

Embora a resposta que se sagrou vencedora, após o quarto século, tenha sido um "sim”, muitos influentes teólogos patrísticos do início do segundo século não hesitaram em responder negativamente. Dentre eles, destacavam-se o já mencionado Marcião e, também, Valentim (105165, aproximadamente) - um líder cristão da Alexandria que, a exemplo de Marcião, se dirigiu a Roma, trazendo consigo um conjunto complexo de idéias gnósticas gregas que pudessem ser utilizadas para elaborar uma teologia cristã essencialmente diferente da judaica. Se as doutrinas desses teólogos tivessem, no fim das contas, prevalecido, não haveria qualquer razão para que a Bíblia hebraica tivesse que ser transferida para os cristãos como um de seus próprios livros sagrados. Entretanto, mesmo asseverando que "no $A n$ tigo Testamento a idéia de 'salvação' aparece somente no sentido elementar e racional de liberação dos males concretos" (Weber, 1965 [1922], p. 44), Weber considerava inconcebível qualquer tipo de cristianismo à margem desse livro. Assim, em seu Ancient Judaism ele assegurou que se Paulo não tivesse transferido o Antigo Testamento para os cristãos, "seitas gnósticas e mistérios do culto de Kyrios Christos teriam existido no solo helênico, mas não teriam proporcionado uma base para a Igreja cristã ou para uma ética cristã do dia-a-dia" (Weber, 1952, p. 4). 
Na próxima sessão, deter-me-ei na expressão "ética cristã do dia-a-dia", uma vez que por meio dela Weber está sugerindo algo, crucial para sua linha geral de argumentação, que pretendo contestar, a saber, que se uma ética cristã não tivesse substituído a ética característica do judaísmo farisaico do primeiro século nenhum padrão racional de conduta concebível poderia ter surgido naquela época. Por ora, entretanto, devo me voltar para a afirmação de que nenhuma verdadeira Igreja cristã poderia ter surgido sem a ajuda das escrituras judaicas. Trata-se, na verdade, de um equívoco, porque, conforme apontou o historiador da religião Burton Mack, no início do segundo século a doutrina de Marcião - segundo a qual o Cristianismo só poderia ter sua própria identidade se cortasse todos os laços com os judeus, com suas escrituras e com qualquer coisa remotamente relacionada a seu Deus da espada e da vingança - "foi ouvida em Ponto, Éfeso e Roma. Congregações se formaram, uma escola se fez, e uma Igreja marcionita se espalbou por todo o império e em direção ao leste. Vilas inteiras tornaram-se cristãs marcionitas, e os marcionitas desafiaram os teólogos centristas por centenas de anos" (Mack, 1996, p. 253, grifos meus).?

Sendo Weber tão excepcionalmente erudito, ele certamente sabia que o cristianismo marcionita havia se difundido. Por alguma razão, entretanto, ele ignorou este fato. Se não o tivesse feito, ele não teria descrito a missão Paulina da forma como o fez, isto é, como um empreendimento tão excepcionalmente bem-sucedido e decisivamente importante. Ele não teria afirmado, por exemplo, que o trabalho missionário de Paulo "ergueu uma cerca robusta contra toda intrusão do intelectualismo grego, especialmente o gnóstico" (Weber, 1965 [1922], p. 259). A força exibida pelas doutrinas teológicas de Marcião e Valentim no início do segundo século leva-nos a duvidar de que uma "cerca" de tal natureza tenha sido erguida algum dia. Em conseqüência, se o cristianismo conseguiu forjar, para si próprio, a imagem de uma religião que superou o judaísmo no plano teológico, isto não ocorreu, como a linha weberiana de raciocínio nos levaria a pensar, por causa do trabalho (supostamente emancipatório) da missão de Paulo. ${ }^{10}$ Ao contrário, isto foi o resultado de um longo e extenuante esforço, cujo ponto de partida foi uma reação, dos teólogos patrísticos, à tentativa marcionita de separar completamente o cristianismo do judaísmo. Afinal de contas, conforme Mack mostrou, após a pregação de Marcião, os cristãos não poderiam mais meramente pressupor que o Deus e pai de Jesus Cristo era o mesmo Deus de Israel; que eles próprios, os cristãos, ao mesmo tempo em que deveriam ser gratos às normas éticas e aos sentimentos veiculados pelas escrituras judaicas, deveriam também rejeitar a Lei judaica, e que o sentido principal da aparição de Jesus era, como apregoava Paulo, a expansão da noção de Israel, de forma a incluir os gentios (Mack, 1996, p. 259).

Disso resulta que, se o cristianismo finalmente tornou-se uma religião mundial, isto dependeu muito mais do sucesso dos apologistas patrísticos em compatibilizar o Deus das escrituras judaicas com o Deus do Novo Testamento do que de um presumido empenho (ou sucesso) da missão Paulina em livrar os judeus de sua presumida condição de "povo pária" expandindo a noção de Israel. Há de se perguntar, entretanto, por que a visão gnóstica de Marcião foi tão contestada no segundo século. Por que tantos pais da Igreja reagiram à sua doutrina de forma tão vigorosa, mesmo após sua morte? Por que, em outras palavras, eles insistiram em se manter ligados às escrituras judaicas, a despeito de todas as inconsistências, de um ponto de vista teológico, que tal decisão poderia acarretar?

A visão que o cristianismo forjou a respeito do seu próprio desenvolvimento levar-nos-ia a responder que as escrituras judaicas tinham que ser mantidas para que se tornasse compreensível o sentido da morte e da ressurreição de Jesus. Esta não é, entretanto, uma resposta muito boa, se tivermos em mente que no segundo século, e mesmo nos séculos subseqüentes, era perfeitamente possível compreender o sentido da morte e da ressurreição de Jesus nos marcos do arcabouço gnóstico trazido a Roma por teólogos como Valentim. Portanto, a profecia hebraica não era necessariamente imprescindível para a validação do argumento de que Jesus morreu e ressuscitou por alguma boa razão teológica. ${ }^{11}$ Por que, então, a insistência em manter o laço com o judaísmo? 


\section{2}

Até meados do segundo século, o cristianismo não havia ainda conseguido forjar sua unidade. Faltava-lhe uma voz unânime, ou algo próximo disso, pois as igrejas ditas cristãs se achavam bastante espalhadas, funcionando cada qual a seu modo, com seus respectivos bispos desfrutando de grande autonomia. Nessa época, um grande número de novos líderes começou a afluir para Roma. Era o início de um processo que se estenderia por mais de cem anos (Webb, 1998). Marcião e Valentim foram dois dos primeiros líderes a chegar. Ambos imaginavam que a unidade cristã só poderia ser obtida se o cristianismo pudesse ser visto como uma novidade, isto é, como uma nova maneira de pensar a respeito de Deus, dos seres humanos e do mundo. Este clamor por novidade foi sedutor por algum tempo, mas, a partir de certo momento,

[...] ficou claro que a própria idéia [gnóstica] dos cristãos serem uma "raça" nova, filhos de um Deus completamente novo e tornado conhecido em tempos recentes por meio de um mensageiro vindo de um outro mundo, desafiava frontalmente toda sensibilidade cultural e toda convicção filosófica no mundo greco-romano (Mack, 1996, p. 161).

Para resumir uma longa história, Marcião e Valentim estavam apresentando o cristianismo como uma novidade, e havia ficado claro que "novidade não era um sinal de sabedoria no mundo greco-romano. O que as pessoas queriam era uma sabedoria enraizada em tempos antigos e digna da história ilustre de seu próprio povo e cultura" (Idem, p. 261). ${ }^{12}$ O homiliasta J. Webb expôs esse mesmo ponto de vista de uma maneira que vale a pena reproduzir:

[...] tanto para a mente romana como para a grega uma religião "nova" não era algo que merecesse muito crédito. Para ser respeitada e amplamente aceita, uma religião tinha que ser antiga, tinha que ter raízes no passado, de preferência em um passado remoto. Em certo sentido, isto se tornou a pedra de toque do impulso cristão para "criar" um passado para si próprio, não só na acepção histórica do termo [...], mas, sobretudo, na acepção teológica, isto é, um passado cuja origem remontasse à própria mente de Deus (1998, p. 3).
Essas considerações levantam uma questão absolutamente crucial: como foi possível aos cristãos criar tal passado teológico para si próprios de forma a permitir que o cristianismo finalmente pudesse alcançar sua unidade e encontrar seu lugar no Império? Devo dizer prontamente que isso nada tem a ver com o trabalho missionário de Paulo. Afinal, mesmo tendo Paulo pregado por toda a Grécia, quase um século após sua morte ainda continuava difícil para um grego compreender sua pregação: o que poderia ser, por exemplo, um deus martirizado, ou uma ressurreição corpórea, ou uma nova ordem mundial advinda desta ressurreição? (Mack, 1996, pp. 262ss.). Esta "conversa" cristã certamente soava tola se comparada com a sabedoria produzida pelas escolas clássicas de filosofia grega. Havia, então, uma difícil missão a ser cumprida: mostrar aos gregos que tudo o que os cristãos diziam fazia sentido até mesmo nos termos dos próprios gregos. É aqui que Justino, o mártir, o apologista patrístico mencionado na sessão introdutória deste artigo, que, a exemplo de Marcião e Valentim, deixou sua terra natal (a Samária) para se dirigir a Roma, entra em cena e, por assim dizer, a "rouba". É melhor deixar que o historiador Burton Mack diga qual foi o extraordinário feito teológico de Justino:

Olhem para nós [os cristãos] e nosso elevado padrão moral, Justino disse, e vejam vossas próprias orgias e festivais de bebedeira. Alguma coisa deve estar errada com vossos deuses e deusas. Olhem para eles: orgulhosos, invejosos, licenciosos e traiçoeiros. Certamente não foi com eles que vossos filósofos aprenderam sobre a virtude. Sabem de onde vem a sabedoria de vossos filósofos? Ela vem de Moisés. Foi lendo Moisés que eles descobriram a sabedoria (sophia) e a razão (logos) de Deus, a qual criou o mundo e continua a mantê-lo. E um deles, Sócrates, estava mesmo disposto a morrer pela verdade. Ora, que grego já se dispôs a morrer por Sócrates? Agora vejam o caso de Jesus. Ele não apenas conhecia o pensamento (logos) de Deus como os filósofos o conhecem, mas o conhecia como filho de Deus, ou sua auto-expressão (logos) pessoal. E revelou a sabedoria e o pensamento de seu Pai pela maneira como viveu, como a própria encarnação da mensagem (logos) do Pai para nós. Em decorrência, vejam quantos cristãos estão dispostos a morrer por ele. Esta é então a sabedoria adequada tanto para um filósofo como para um teólogo (Idem, p. 263, grifos do autor). 
Os filósofos gregos obtiveram acesso à sabedoria e à razão divina por intermédio de Moisés! Mas, e quanto a Moisés? Como ele próprio obteve sua sabedoria? Teria sido por intermédio de Deus, cuja voz escutava em certas circunstâncias, como os judeus estavam acostumados a pensar? Não, responde Justino. Moisés adquiriu sua sabedoria ouvindo, não a Deus diretamente, mas ao "primeiro logos criado por Deus", ${ }^{13}$ isto é, o filho de Deus. Quando, por exemplo, lemos Êxodo 3:2-10, imaginamos que a voz que Moisés escuta - vindo da "sarça ardente", dizendo: "Eu sou o Deus de seus pais, o Deus de Abraão, o Deus de Isaac e o Deus de Jacó" (Ex; 3:6); "Eu vi, eu vi a miséria do meu povo que está no Egito" (Ex; 3:7) etc. - é a do próprio Deus. Mas Justino não pensa assim. "Quando Deus fala, ai de nós!, não é mais Deus quem fala", teria dito Justino se pudesse ter lido Schiller. ${ }^{14}$ Como não pôde, recorreu a Isaias 1:3 ("mas Israel é incapaz de conhecer, meu povo não é capaz de me entender") para provar que a voz que se dirigia a Moisés não podia ser a de Deus mas, sim, a de Jesus.

Estamos, portanto, diante de um épico no qual um Jesus etéreo fala a um Moisés de carne e osso, cuja pregação é a fonte da sabedoria da filosofia clássica grega! Este foi o grande feito teológico e filosófico de Justino (Mack, 1996, pp. 259273). O cristianismo precisava de um passado teológico. Justino lançou as bases para que tal passado pudesse ser criado ao fazer de Moisés um personagem da história do cristianismo; ao converter o passado judaico em um passado cristão, isto é, ao encontrar uma maneira de ler a história de Israel como a história do Deus cristão; como uma história que contava como o épico cristão e não como o épico de Israel, o qual apontava em direção ao estabelecimento de uma teocracia judaica em Jerusalém (Idem, p 268). No coração de todo esse empreendimento estava uma única palavra: logos,

[...] a noção grega que escorregou, quase que incidentalmente, para o Evangelho de João, bem no início do segundo século. O logos de João revelava a "mente de Deus", assim argumentava o evangelho; ademais, palavras similares a $\log o s-$ "a mente de Deus" - estavam espalhadas por todas as escrituras hebraicas, a começar dos longínquos mitos da criação, presentes no Gênesis.
Justino desenvolveu o argumento de que Jesus estava presente o tempo todo. As escrituras hebraicas versavam sobre Jesus, afinal. Assim, tudo o que se fazia necessário era encontrar as referências a Jesus - por mais escondidas ou veladas que estivessem - e segui-las até o final. As profecias hebraicas, e havia muitas, não eram, então, o que aparentavam; o que elas verdadeiramente faziam era anunciar a chegada de Jesus. A "palavra" de Deus que já se ouvia desde Abraão, Isaac e Jacó era, na verdade, a voz de Jesus. Nessa perspectiva, Marcião, com sua obstinada rejeição das escrituras hebraicas, constituía um obstáculo para o desenvolvimento do cristianismo. Não se tratava de rejeitar o judaísmo, mas de rever a história judaica de tal forma que ela culminasse em Jesus, e não no estabelecimento de um estado judeu sediado em Jerusalém. Isto significava rearranjar as escrituras hebraicas de forma tal que o último livro fosse o de Malaquias, em vez das Crônicas. Significava também criar uma teologia que sustentasse que o Deus e Pai de Cristo era o mesmo "Deus" que havia tentado, em vão, conduzir o povo judeu por séculos (Webb, 1998, p. 3). ${ }^{15}$

Sugiro que essa teologia, constituída a partir do empenho dos teólogos do segundo século, notadamente de Justino, em transformar o passado judaico em um passado cristão mediante o argumento de que o povo judeu foi incapaz de realizar, ou mesmo de perceber, aquilo que seus próprios profetas haviam anunciado, e hoje conhecida pejorativamente, até mesmo pelos próprios cristãos, como "teologia da superação", é o empreendimento intelectual que, desde os escritos seminais de Max Weber, se encontra na base de toda discussão sociológica a respeito do processo de racionalização ocidental. Afinal, se tal empreendimento não tivesse sido bem-sucedido, não teria sido possível atribuir às missões de Paulo, ocorridas quase três séculos antes, a importância teológica e histórica que retrospectivamente se lhes atribuiu e, conseqüentemente, não teria também sido possível atribuir a essas missões o papel tão crucial (na evolução da ética ocidental) que Weber, Parsons e, recentemente, Schluchter lhes atribuíram. Assim, sem o alicerce propiciado por essa teologia, que sentido poderia fazer a tese weberiana de que a profecia hebraica trazia em germe certas concepções inovadoras (como, por exemplo, o próprio monoteísmo), cujas potencia- 
lidades éticas o povo judeu, em razão de sua condição de pária, não foi capaz de desenvolver e, portanto, foi necessário que o judaísmo farisaico viesse a ser substituido, ou superado, pelo cristianismo Paulino, para que tais potencialidades pudessem, de fato, ser desenvolvidas? Ou, ainda, como compreender a grande admiração de Weber por Paulo e seu trabalho missionário? - admiração que, diga-se de passagem, torna-se particularmente nítida se atentarmos para o fato de Weber ter identificado, no episódio de Antioquia (Gálatas, 2:11), onde Paulo, em contraste com Pedro, sentou-se à mesa com os gentios, um dos três momentos chaves da história da cultura ocidental (Weber, 1993, pp. 322-323). ${ }^{16}$

Da mesma forma, pode-se perguntar se sem o lastro proporcionado por essa teologia, a sociologia de matriz weberiana poderia ter formulado a tese de que o advento do cristianismo significou uma "revolução de valores últimos", ${ }^{17}$ ou sugerido que as missões Paulinas purgaram a Torá "de todos os aspectos da ética imposta por ela que ritualmente caracterizam a posição especial dos judeus como um povo pária" (Weber, 1952, p. 4) ou, ainda, postulado a existência de uma "ética cristã do dia-a-dia" (Idem, ibidem), moldada a partir do universalismo Paulino, que teria substituido, ou superado, uma ética farisaica dual, baseada em tabus, peculiar à existência pária dos judeus, exemplificada pelo comportamento de Pedro no episódio de Antioquia. Seria viável tudo isso à margem da teologia cristã da superação?

\section{3}

Minha resposta é, evidentemente, não. Para justificá-la, vou iniciar relembrando a tese de Weber, exposta no Ancient Judaism, de que graças ao trabalho missionário de Paulo foi possível surgir uma "ética cristã do dia-a-dia" ao final do primeiro século, em substituição à então prevalecente ética farisaica. Weber não diz (no Ancient Judaism) em que exatamente consistia essa ética que acabara de surgir, mas é muito claro a respeito do tipo de ética que havia sido superada: tratava-se da tradicional "ética da retribuição", ${ }^{18}$ característica das "classes não-privilegiadas", e que, no caso específico dos fariseus, pressupunha um homem "fraco, como uma criança e, portanto, inconstante em sua vontade e sujeito a pecados, isto é, à desobediência ao criador paterno" (Weber, 1952, p. 400). Em resumo, o que havia sido superado era uma ética religiosa que demandava, sobretudo, "uma obediência de criança ao monarca do mundo" (Idem, ibidem). Em um contexto inteiramente diferente, Weber faz referência a um padrão de conduta que "não consiste em uma sistematização vinda de dentro, irradiando a partir de um centro que o próprio indivíduo logrou estabelecer" (Idem, 1965 [1922], p. 190). Seu alvo, ao fazer tal afirmação, não foi os fariseus, mas sua linha de raciocínio autoriza-nos a afirmar que ele lhes atribuiria, também, tal padrão heterônomo, infantil de conduta. Além disso, Weber mostra-se bastante agradecido a Paulo por ter este último oferecido aos seres humanos uma oportunidade (que só viria a ser verdadeiramente aproveitada um milênio e meio mais tarde, pelos protestantes calvinistas) de se comportar autonomamente, como se espera de um adulto.

Mas, devemos mesmo ser tão agradecidos a Paulo? Alguns sociólogos têm se apoiado nos ombros de Weber para dar a entender que sim. Schluchter, por exemplo, em seu já citado livro Rationalism, religion and domination, sugere que a passagem de Paulo significou uma "reviravolta dos valores tradicionais" - por "tradicionais", é importante esclarecer, Schluchter quis dizer, exatamente, farisaicos. Nos marcos do "arcabouço tradicional", Schluchter argumenta, "havia a 'lei' controlando o espírito'; agora é o 'espírito' que controla a 'lei'." Essa transição, de acordo com ele, "levou à flexibilidade na aplicação das normas" (Schluchter, 1989, p. 206). Há de se indagar, entretanto, se alguma "reviravolta" ocorreu mesmo em razão da passagem de Paulo e, em caso afirmativo, se consistiu, como afirmou Schluchter, em uma "reavaliação da relação entre 'espírito' e 'lei' de forma a proporcionar novos meios de conceber a natureza da 'lei' e o alcance de sua validade sem, entretanto, anulá-la" (Idem, pp. 206-207). Curiosamente, há teólogos cristãos (e judeus também, naturalmente) que não só negariam que tal "reavaliação" tenha ocorrido (porque, na verdade, nada havia para ser "reavaliado") como, também, não parecem ter por Paulo, o suposto arquiteto dessa suposta "reavaliação", tão 
elevado apreço. Deixemos que um deles, o teólogo protestante Lloyd Gaston, fale por si:

A abolição da Lei por Paulo é o que mais tem aborrecido não só os intérpretes judeus, mas a quem quer que tenha algum conhecimento sobre o conceito de Torá nos escritos judaicos. Não é tanto a invectiva de Paulo o que incomoda, mas sua ignorância. Para quem compreende o judaísmo rabínico, os ataques de Paulo são não apenas injustos, mas totalmente fora de propósito. Os rabinos nunca falam da Torá como um meio de salvação, e quando falam em salvação, se é que o fazem, o modo da Torá, "que é a vossa vida" (Dt: 32:47), é esta salvação. O zelo ético dos rabinos torna-se ainda mais fervoroso em razão de acreditarem que os mandamentos expressam a vontade de Deus para o bem de Israel, mas eles jamais podem, por isto, ser tachados de legalistas. Fé e obras jamais podem ser vistos como opostos, pois cada um se tornaria sem sentido sem o outro. A lei não é sentida como um fardo (quando o é, é modificada), e a frase característica é "o júbilo dos mandamentos". Longe de ser um estímulo ao pecado, ou a maldição da condenação, a lei é o meio misericordioso de Deus ajudar as pessoas a superar seus "impulsos malignos". Não há qualquer indicação de que Paulo fosse ciente de que muitas das leis dizem respeito aos meios de arrependimento, os quais pressupõem o pecado humano, mas, em contrapartida, proclamam o perdão divino. É extremamente significativo que o conceito de arrependimento, tão central tanto para a teologia rabínica como para a doutrina de Jesus, nunca ocorra em Paulo. Como G. F. Moore observou: "o fato de um judeu com os antecedentes de Paulo ignorar, e por implicação negar, a grande doutrina profética do judaísmo, a saber, que Deus, a partir do amor, livremente perdoa o pecador sinceramente penitente e o restaura para sua proteção, parece, de um ponto de vista judaico, inexplicável (Gaston, 1987, pp. 18-19).

Devo deter-me na expressão "o modo da Torá" porque ela aponta para algo que a linha de raciocínio de Weber nos impediria de entreter, a saber, a existência, entre os fariseus, daquilo que Weber, ele próprio, chamou de "um padrão de conduta que seja uma sistematização vinda de dentro, irradiando a partir de um centro que o próprio indivíduo logrou estabelecer". Fiel à sua abordagem "desenvolvimentalista", Weber concebia vários estágios no desenvolvimento da ética religiosa. Em um estágio primitivo, ela é freqüentemente composta "por um conjunto de prescrições e proibições heterogêneas, derivadas dos mais diferentes motivos e ocasiões. Nesse conjunto, há pouca diferenciação entre exigências importantes e sem importância; qualquer infração da ética constitui pecado" (Weber, 1965 [1922], p. 44). A afirmação de Weber, à qual já fiz alusão, de que "no Antigo Testamento a idéia de 'salvação', prenhe de conseqüências, ainda tem o significado racional elementar de liberação dos males concretos" (Idem, ibidem), conjugada com sua insistência em enfatizar o caráter "tabuístico" do judaísmo farisaico, autoriza-nos a inferir que Weber incluiria a ética religiosa farisaica nesse estágio primitivo.

Mas ética religiosa é algo que evolui. Isso ocorre quando após algum tempo passa a haver um melhor entendimento a respeito de o que constitui um pecado ou o que conta como uma exigência ética importante. Nesse caso, uma transformação radical pode acontecer: o desejo racional de assegurar prazeres pessoais para si próprio realizando ações que agradem a Deus pode ser substituído por uma concepção do pecado como o poder unificado do antidivino em cujas garras o homem pode cair. Na medida em que tal substituição ocorre, a "bondade" começa a ser vista como uma capacidade integral para uma atitude de santidade, como também para um comportamento consistente derivado de tal atitude. Este é o estágio mais racionalizado que uma ética religiosa pode alcançar, especialmente se durante a transição se desenvolve "uma esperança por salvação concebida como um anseio irracional por ser bom sem ganhar nada com isto, a não ser a própria consciência gratificante de sê-lo" (Idem, ibidem).

A expressão "o modo da Torá", na citação acima, refere-se exatamente a esta "atitude de santidade" que acabo de mencionar, em conjunto com o "comportamento consistente" dela derivado. Em outras palavras, refere-se exatamente a algo que Weber supôs inconcebível entre os fariseus: uma ética altamente racionalizada, caracterizada por "um anseio irracional" por seguir os mandamentos meramente por segui-los. Que tenha surgido, contra as expectativas de Weber, tal forma racionalizada, sublimada, de piedade entre os fariseus, é algo que pode ser entendido se nos detivermos em uma breve asserção dele 
próprio em Ancient Judaism, a saber, que uma "esperança messiânica [...] foi por toda parte mantida pelos fariseus" (Idem, 1952, p. 390). Isto é verdade, naturalmente, mas deve-se perguntar que tipo de esperança messiânica era esta. Pretendo mostrar que uma vez entendida a natureza da esperança messiânica farisaica ficará imediatamente claro o quanto Weber se equivocou ao supor impossível uma ética racionalizada entre os fariseus e o quanto Schluchter errou o alvo ao propor, ancorando-se em Weber, que o advento dos primeiros movimentos cristãos significou uma "reviravolta dos valores tradicionais".

Retomemos, então, à questão-chave: qual a natureza da esperança messiânica mantida pelos fariseus? Weber responderia que se trata da "esperança racional elementar de liberação de males concretos", característica de toda "religiosidade de retribuição". Receio, entretanto, que esta não seja uma boa resposta. Para explicar isso, devo recorrer aos escritos de um estudioso ímpar do judaísmo farisaico, o teólogo Jacob Neusner:

\begin{abstract}
Os autores do Levítico e do Deuteronômio, dos livros históricos de Josué a Reis, e a literatura profética concordavam que quando Israel fazia a vontade de Deus, era recompensado com paz, segurança e prosperidade; quando desobedecia, era punido pelas mãos de reinos poderosos que surgiam como instrumentos da ira divina. Esse modo de conceber o significado da vida israelita levantou a questão: por quanto tempo? Quando os grandes eventos da história conheceriam seu clímax e conclusão? A esperança pelo Messias o ungido de Deus, que redimiria o povo e o colocaria no caminho para sempre, acabando, dessa forma, com as vicissitudes da história - surgiu como uma resposta para essa pergunta (1991, p. 10).
\end{abstract}

Esta passagem poderia muito bem ter sido escrita pelo próprio Weber. Afinal, o que mais ela oferece senão uma bela ilustração daquilo que Weber chamou de "religiosidade de retribuição", caracterizada por uma "obediência de criança" a um monarca celestial todo-poderoso que um dia apontará (ungirá) aquele que livrará seu povo dos "males concretos" que sempre o afligiram? E, de fato, se não fosse pela expressão "uma resposta", a qual sugere que pode ter havido pelo menos mais uma (como de fato houve, conforme vere- mos), não haveria diferença entre a perspectiva de Weber e a de Neusner sobre a religiosidade farisaica. Acontece, entretanto, que o anseio por um redentor, tal como descrito na citação acima, já não é mais uma característica do judaísmo farisaico desde o final do primeiro século. ${ }^{19}$ Devo passar a palavra a Neusner novamente:

Quando chegamos ao primeiro século da era comum, assistimos a uma mudança radical da natureza da esperança messiânica farisaica. Quem quer que seja familiarizado com os evangelhos não se surpreenderia em saber da grande e viva expectativa, prevalecente entre alguns grupos, da chegada do Messias. As pessoas que fixam sua atenção em eventos de seu próprio tempo, cujos desdobramentos são catastróficos, esperam, naturalmente, por um futuro melhor. Tal expectativa constitui, então, um contexto para o mito messiânico. Mais surpreendente, entretanto, foi o desenvolvimento, entre o povo de Israel, de uma segunda resposta à história, de natureza radicalmente distinta. Trata-se da resposta daqueles preparados de uma vez por todas para transcender os eventos históricos e se despedir das guerras e rumores de guerra, da política e da vida pública. Essas pessoas, após 70 d.C. [ano da destruição, pelos romanos, do segundo templo de Jerusalém], empenharam-se em construir uma nova realidade, para além da história, que enfocava o significado dos afazeres comezinhos da vida cotidiana. A sabedoria compilada na Mishnah não mostra covardia, nem passividade diante de eventos catastróficos, mas o início de um novo modo de ser. Os sábios resolveram exercer uma liberdade não controlada pela história [...]. Eles empreenderam uma busca pela eternidade no aqui e agora; lutaram para estabelecer uma sociedade capaz de se manter em meio à mudança e à tensão. Na verdade, esta era uma nova interpretação do significado da história. As nações do mundo supunham que "faziam" a história e que suas ações importavam. Mas esses sábios sabiam que Deus faz a história, e que é a realidade formada em resposta à vontade de Deus que conta como história [...]. Esta nova concepção de tempo e de mudança constituiu o início de uma tradição sacerdotal que mais tarde teve continuidade no judaísmo chamado rabínico ou talmúdico (Neusner, 1991, pp. 10-11, grifos meus).

O contraste entre este longo excerto e aquele igualmente longo de Weber, reproduzido na sessão introdutória deste artigo, não poderia ser maior. Ambos referem-se ao judaísmo farisaico do 
primeiro século. ${ }^{20}$ Entretanto, enquanto Weber vê um judaísmo "tardio", ou mesmo esgotado, engessado em centenas de prescrições rituais e tabus, e em boa hora sendo substituído por uma forma mais "flexível" (como o diria Schluchter) e "emancipatória" de religiosidade, representada pelo cristianismo Paulino, Neusner, cuja linha de raciocínio não se desenvolveu sob o guarda-chuva da teologia cristã da substituição, vê um judaísmo que está apenas começando. Nesse novo judaísmo, renascido das cinzas do Segundo Templo, um certo tipo de esperança messiânica, ou um certo modo de experimentar e interpretar os grandes eventos, que pode ser chamado bistórico, foi substituído por outro, que pode ser chamado meta-bistórico. O modo histórico enfatiza a importância intrínseca dos eventos e se interessa por seu peso e significado. Nesse sentido, ele reivindica conhecer "o segredo da história, a época da salvação e o modo pelo qual podemos nos redimir" (Idem, p. 11). O modo meta-histórico, em contraste, ignora os grandes eventos e realça, em contrapartida, a "construção de um modo de ser eterno, imutável neste mundo, capaz de pairar acima das vicissitudes da história" (Idem, p. 12).

Nos marcos desta imagem do judaísmo farisaico como um modo meta-bistórico de abordar a vida, no qual a atenção do fiel é dirigida para o "significado último contido nos menores e mais modestos afazeres" (Idem, p. 11), nada haveria de surpreendente em ouvir, por exemplo, do historiador fariseu Flávio Josefo (37-100 d.C.), que

[...] muitos povos, e desde muito tempo, mostram um grande interesse por nossas práticas piedosas. Não há uma só cidade grega e nem um povo bárbaro para onde não se tenham estendidos nossos costumes do repouso semanal e onde não se guardem os jejuns, as lamparinas acesas e muitas regras a respeito da comida (Contra Apião $2: 282)^{21}$

Da mesma forma, não ficaríamos surpresos de ouvir que "durante toda a antiguidade, os pagãos, os judeus e vários cristãos continuavam a se misturar nas sinagogas; a se encontrar em eventos culturais e cívico-esportivos; a se encontrar em cerimônias oficiais e nos banhos [...]. Esta conexão cultural perdurou mesmo após a conversão de Constantino" (Fredriksen e Lieu, 2004, pp. 88-89).
Tudo isso está claramente em desacordo com a tese weberiana, realçada por Schluchter, de que a "judiaria da diáspora" constituía uma "comunidade especial, fechada para o mundo exterior através de barreiras rituais" e "com baixa capacidade de difusão" (Schluchter, 1989, p. 199). Em resumo, a tese weberiana, muito pouco discutida na literatura sociológica, de que os judeus constituem um povo pária, escravizado por um legalismo que foi abolido pelo trabalho missionário de Paulo, não faz justiça às relações de fato existentes entre judeus, pagãos e cristãos nos primeiros séculos da era comum. Em relação a tudo isso, vale a pena mencionar que o próprio Schluchter contestou, ainda que de forma bastante tímida, a tese weberiana do povo-pária, ao afirmar, valendo-se de um livro publicado em 1937 (Causse, 1937), que se trata de "uma projeção retrospectiva da fase do desenvolvimento medieval sobre a antiguidade" (Schluchter, 1989, p. 178). ${ }^{22}$

Mas, contestar este caráter de povo pária que Weber atribui aos judeus é vislumbrar no arcabouço religioso judaico alguma possibilidade de inclusão de não judeus. Seria, entretanto, concebível tal inclusão? Em outras palavras: teria o arcabouço religioso judaico um alcance universal?

\section{4}

Dentre os livros da Bíblia hebraica que mereceram de Weber uma atenção especial, há um diretamente endereçado a essa questão. Refiro-me ao livro conhecido por Deutero-Isaias (Isaias 40-55). Weber tinha por este livro o mais elevado apreço, por supor que seu autor, diferentemente de todos os outros profetas bíblicos, não estava preocupado meramente com o futuro de Israel; "O problema" desse autor anônimo, Weber enfatizou, era "a teodicéia do sofrimento de Israel na perspectiva universal de um governo mundial sábio e divino" (Weber, 1952, p. 375). Assim, Deutero-Isaias é, para Weber, um livro único porque traz consigo uma "teodicéia do sofrimento", de acordo com a qual Deus possui um plano sagrado para todo o mundo, e não somente para o benefício de Israel.

De acordo com Weber, o autor anônimo de Deutero-Isaias via na experiência devastadora do e- 
xílio babilônico nada mais que um meio (na verdade, o mais importante) para a realização do plano sagrado de Deus. Em outras palavras, Deus tinha um plano para toda a humanidade cuja realização só seria possível se Israel fosse "purificado". Sendo este o caso, o destino ignominioso de Israel era apenas um meio de purificação: "Yahweh não purifica seus fiéis 'como se refina a prata', afirma Weber, parafraseando Isaias 48:10, "mas o torna seu 'povo escolhido' na 'fornalha da aflição'” (Idem, p. 371). Assim, enquanto a pregação profética hebraica pré-exílio supunha que o sofrimento fosse meramente uma punição pelo pecado, ou uma advertência para fazer penitência, em Deutero-Isaias esse padrão foi amplamente superado por uma valorização do sofrimento per se como um meio de obter salvação. Na medida em que Deutero-Isaias "glorifica o sofrimento imerecido" como um meio de cumprir uma missão soteriológica, este "livro extraordinário", como Weber a ele se referiu, encerra a "ética específica da humildade e da não-resistência revivida no Sermão da Montanha" (Idem, p. 376).

Se é verdade que Deutero-Isaias encerra uma "ética específica da humildade e da nãoresistência", cabe perguntar de que tipo de "humildade" e de "não-resistência" está se falando. Será da "humildade" e da "não-resistência" revivida no Sermão da Montanha, como Weber o asseverou? Receio que não. A humildade e a nãoresistência apregoada no Sermão da Montanha encerra uma esperança messiânica totalmente desconectada de preocupações nacionais e políticas. Em decorrência, o reino da terra é separado do reino divino, algo inaceitável para toda a literatura profética, que sempre "coloca sua esperança na dinastia de Davi e na restauração de um reino justo e bem-sucedido" (Shmueli, 1968, p. 221). Portanto, ao sugerir que o Sermão da Montanha "revive" a prédica do autor anônimo de Deutero-Isaias, Weber está ignorando o fato de que a "humildade" e a "não-resistência" apregoadas em Deutero-Isaias estão relacionadas com a elevação do reino terrestre, e não com sua negação. É conveniente recorrer, para explicar melhor essa questão, a um estudioso do assunto, o já mencionado scholar Efraim Shmueli:

Weber afirmava repetidamente que a doutrina profética atingia, sobretudo, um estrato "plebeu", da mesma forma que uma ética do dia-a-dia era essencialmente "plebéia" por causa de sua afinidade com esse estrato [...]. A justificação do sofrimento tinha um apelo particular ao estrato plebeu, ao pobre e humilde, que acreditavam ser piedosos e justos. A moralidade profética não poderia ser aceita por um nobre militante, um rico proprietário de terra ou em uma corte principesca. Entretanto, isto é uma visão equivocada, influenciada pela idéia defendida por Nietzsche, em A genealogia da moral, de que a moralidade defendida pelas doutrinas proféticas tem um caráter plebeu, ou constitui a fonte de uma religiosidade cultivada por grupos de status que têm uma existência pária. Os estratos mais baixos - argumentaram Nietzsche e Weber -, particularmente os pobres e os expropriados, quando não reconhecem a astúcia e a fraude como armas legítimas em sua luta pela sobrevivência, tornam-se piedosos e celebram a humildade e a subjugação como virtudes morais em si mesmas. Nietzsche rejeitou esta "moralidade de escravos" como uma forma disfarçada de ressentimento. Entretanto, a moralidade profética era revolucionária e heróica. Ela protestava contra a subjugação social e econômica, como também contra toda ausência de poder que colocava alguns homens nas mãos de outros. O sofrimento que resultava da opressão social não era celebrado. O livro Deutero-Isaias aclamava o sofrimento como um serviço prestado à causa divina para acelerar a salvação. Convictos de que representavam a causa de Deus, os profetas foram capazes de enfrentar os poderosos. Em períodos posteriores, quando a luta aberta se revelou impossível, a paciência heróica tornou-se a característica do povo judeu (Idem, pp. 221-222).

Se a ética da "humildade" e da "não resistência" apregoada em Deutero-Isaias foi de alguma forma "revivida" em uma época posterior, como Weber o sugeriu, seria muito mais apropriado dizer que ela foi revivida na forma da "heróica paciência" mencionada acima, do que na forma de uma "glorificação do sofrimento imerecido" tal como expressa no Sermão da Montanha. Afinal, "paciência heróica" é claramente algo que diz respeito ao modo meta-histórico de abordar a vida - o qual enfatiza o significado último dos afazeres comezinhos da vida cotidiana -, característico, conforme vimos, do judaísmo após a queda do segundo templo, enquanto a "glorificação do sofrimento imerecido" é algo que diz respeito ao modo bistórico, ou messiânico, de abordar a vida - o qual enfatiza a importância dos grandes even- 
tos. Mas Weber não enxergou essa diferença. O que ele viu foi um modo "humilde" e "não-resistente" de ser, sendo, em um primeiro momento, assumido pelos judeus - acarretando, para os mesmos, uma "conseqüência fatal": "a glorificação da situação de povo pária e sua perseverança nessa situação" (Weber, 1952, p. 375) - e, posteriormente, "revivido" por Jesus em seu Sermão da Montanha. E, embora Weber não o tenha dito, sua linha de raciocínio autoriza-nos a afirmar que, de acordo com ele, é exatamente por causa de ter sido "revivido" no Sermão da Montanha que o projeto, presente em Deutero-Isaias, de colocar a teodicéia do sofrimento de Israel na "perspectiva universal de um governo mundial divino e sábio" pôde ser devidamente executado. Assim, mais uma vez a sociologia de Weber se mostra embebida na teologia cristã da superação: se DeuteroIsaias é um livro relevante histórica, teológica ou mesmo eticamente, é apenas porque concebeu um projeto universalista cuja execução estava condicionada à posterior superação do judaísmo pelo cristianismo.

Aparte Deutero-Isaias, há ainda, na perspectiva de Weber, uma maneira de conferir à Torá um alcance universal, qual seja, purgá-la "de todos aqueles aspectos da ética imposta por ela que ritualmente caracterizam a posição especial dos judeus como um povo pária” (Idem, p. 4). Weber, conforme vimos, supunha que Paulo, por meio de seu trabalho missionário, havido realizado tal tarefa. Os próprios teólogos, entretanto, não atribuem a Paulo tão extraordinário feito. Não me refiro a teólogos judeus, mas aos próprios teólogos cristãos, como Lloyd Gaston, já citado longamente, ou Rosemary Ruether, bastante conhecida por ter cunhado a feliz expressão "teologia da superação".

Assim, em seu célebre Faith and fatricide, já mencionado, Ruether observa que enquanto o cisma entre particularismo e universalismo era um problema maior para a Igreja, o judaísmo já havia encontrado uma solução. Colado no postulado fundamental "toda Israel tem uma parte no mundo vindouro" (Mishnah Sanhedrin 10:1) está o corolário referente aos "justos dentre as nações do mundo que têm uma parte no mundo vindouro" (Talmude Sanhedrin 13:2 - R. Joshua, fim do primeiro século). Nessa perspectiva, seria exatamente a perspectiva universalista de Israel que permite aos não-judeus relacionar-se com Deus à sua própria maneira, que lhe autoriza ter sua maneira particular de relacionar-se com Ele através da aliança do Sinai. Mas, para ser considerado um "justo", é necessário manter alguma forma de relacionamento com o Criador, e não pode haver tal relacionamento à margem da Torá, como também não pode haver Torá à margem dos mandamentos (Gaston, 1987, p. 23).

Nessa perspectiva, o alcance universal do judaísmo farisaico estaria em especificar os mandamentos aos quais todos devessem se submeter. Isto seria possível? Na verdade, não é difícil entreter uma resposta afirmativa. Conforme vimos, teólogos cristãos contemporâneos como Lloyd Gaston, e não tão contemporâneos como George Foot Moore, mostraram-se surpresos pelo fato de Paulo jamais fazer referência à doutrina judaica do arrependimento. Talvez, entretanto, esta omissão não seja algo assim tão surpreendente se tivermos em conta que Paulo se dirigia fundamentalmente a uma audiência culturalmente grega e, por essa razão, o conteúdo de sua pregação podia ser baseado em uma parte da Torá que lidava exclusivamente com não-judeus. ${ }^{23}$ Refirome às chamadas leis de Noé, que seriam mais tarde codificadas por Maimônides. Alguns estudiosos sustentam que elas formavam o núcleo da doutrina de Paulo tal como revelada em suas epístolas. ${ }^{24}$ As leis de Noé são um conjunto muito simples de proibições: à idolatria, a evocar o nome de Deus em vão, ao roubo, ao assassinato, à má conduta sexual e à crueldade com os animais, acrescidas de um mandamento segundo o qual se deveria estabelecer tribunais de justiça que assegurassem localmente a observação dessas proibições. Muitos dos fariseus contemporâneos de Paulo já afirmavam que qualquer gentio que pudesse guardar as sete leis de Noé seria um justo e, portanto, teria seu lugar "no mundo vindouro" (Keener, 2005, p. 538). Nessa perspectiva, a Torá não precisaria ser transferida para os cristãos - ou, como apregoava Weber, ser purgada de seus traços caracteristicamente judaicos - para que fosse possivel lhe atribuir um alcance universal. Afinal, ao encerrar as leis de Noé, ela propicia uma religiosidade sem restrições de laços étnicos ou nacionais ao mesmo tempo em que proíbe qualquer meio institucionalizado de conceder a 
graça. A razão, aliás, para que o arcabouço dessas leis fosse tão "magro" (seis proibições muito simples mais a prescrição do estabelecimento de tribunais locais) é a de que, em seus marcos, o conceito de autoridade religiosa deixava de pertencer a alguma base institucionalizada e passava a ser posto nas mãos dos indivíduos. Por esta razão, ninguém, nem mesmo um rabino, poderia prescrever normas de conduta a, ou ter qualquer autoridade religiosa sobre, um seguidor das leis de Noé.

\section{5}

Nota-se que o argumento aqui desenvolvido envolve uma espinhosa discussão sobre as relações entre o judaísmo e o cristianismo. Entretanto, penso que a sociologia da religião, a menos que deliberadamente desista de abordar certos temas, não pode se furtar a discussões de tal natureza por mais espinhosas que se mostrem. Weber parecia estar ciente da inevitabilidade de discutir no terreno teológico, como se pode concluir da asserção de Friedrich Graf, após ter tido acesso à sua correspondência pessoal, de que "nos últimos anos, Weber repetidamente enfatizou que para ele os interlocutores mais importantes no debate sobre A ética protestante eram os 'especialistas' em assuntos religiosos, os teólogos. Deles somente ele esperava uma 'crítica frutífera e instrutiva"' (Graf, 1993, p. 27, grifos meu).

Ao permitir que sua discussão sociológica se deslocasse para o terreno da teologia, Weber deliberadamente incorreu em certos riscos, mas, se não o fizesse, ele teria que recuar diante de seu principal tema: o processo de racionalização ocidental. Se é verdade que um momento crucial desse processo tenha sido, como se tem sugerido desde Weber, a transição de Saulo, o fariseu, para Paulo, o cristão, então é inevitável discutir a natureza e a real importância dessa transição - algo que não pode ser feito à margem da teologia. Assim, se contestamos (como procurei fazer aqui) a tese weberiana de que havia um particularismo legalista farisaico que veio a ser superado pelo universalismo peculiar ao pensamento Paulino estaremos nos movendo no terreno da teologia. Se, por outro lado, aceitamos essa tese, estaremos, também, nos movendo em um terreno teo- lógico, mais precisamente, nos marcos da teologia cristã da superação. Nesse caso, estaremos permitindo que uma concepção teológica que vem sendo crescentemente rejeitada mesmo no interior do pensamento cristão sirva de quadro de referência para a investigação sociológica. Se parece ser inevitável que nos movamos no terreno da teologia ao estudarmos o impacto sóciohistórico de diferentes doutrinas e práticas religiosas, é melhor que o façamos abertamente.

\section{Notas}

1 Weber enfatiza que este preceito constitui o fundamento de todo o significado "especificamente ocidental de "personalidade", posto que "é em um reino trans-mundano de salvação da transitoriedade que todos os mais elevados interesses da Ásia estão postos e, com isto, a 'personalidade' também acha seu valor" (Weber, 1960, p. 339).

2 De acordo com Weber, a transformação dos judeus em um "povo pária" teve início ainda antes do exílio (586 a.C) e consumou-se com a Restauração judaica, após o exílio (538 a.C), tal como relatada nos livros de Esdras e Neemias. A partir de então, iniciou-se um processo de autosegregação, pois não era mais concedido aos judeus o direito de se casar com gentios, e os casamentos "mistos" já existentes foram desfeitos por decreto. Ver, por exemplo, Neemias 13:23.

3 Seria conveniente reproduzir o argumento de Weber a esse respeito: "[...] o judeu estabeleceu como seu ideal ético [...] o intelectual que dedica a vida ao estudo dos textos sagrados e dos comentários [...]. Foi exatamente esse traço intelectualista do genuíno judaísmo tardio, com sua preocupação com a erudição bíblica, que Jesus criticou. Sua crítica [foi motivada] pela natureza de sua fé e por sua maneira peculiar de obedecer a lei, ambas apropriadas a um artesão rural ou a um habitante de cidade pequena, e ambas constituindo a base da oposição de Jesus aos virtuosos do conhecimento da lei, os quais eram nascidos e criados no solo da polis de Jerusalém. Os membros desses círculos legalistas urbanos perguntavam 'O que pode vir de bom para nós de Nazaré?' - uma pergunta típica de qualquer habitante de cidade grande no mundo clássico" (Weber, 1965 [1922], p. 253).

4 A tese de que a transição do Antigo para o Novo Testamento significou uma transição da "legalidade" para a "moralidade" foi defendida por W. 
Schluchter (1981, p. 69; 1989, especialmente pp. 197ss.).

5 Na verdade, Weber admite uma honrosa exceção. De acordo com ele, a pregação do autor anônimo do livro conhecido como Deutero-Isaias, ao qual oportunamente retornarei, tem um caráter universalista.

6 A obra de Justino resume-se às Apologias I e II e ao Diálogo com Trifão. O cerne do que é hoje conhecido como "teologia da superação" está presente no Diálogo com Trifão, escrito por volta do ano 150.

7 Ao afirmar que, após a missão de Paulo, "o judeu poderia realmente livrar-se das antigas promessas de seu Deus colocando sua fé no novo salvador, que se sentiu abandonado na cruz por aquele mesmo Deus" (Weber, 1965 [1922], pp. 259). Weber está claramente elogiando Paulo por oferecer aos judeus uma oportunidade para abandonar o judaísmo.

8 Conforme apontou o historiador Burton Mack, após a morte de Jesus, "Sectários hassídicos, cultos locais de mistério, mágicos itinerantes, místicos exegetas, filósofos cósmicos e mistagogos gnósticos apelavam todos para o nome de Jesus para validar a fonte ou a verdade de seus respectivos programas" (1996, p. 199)

9 A expressão "teologia centrista" é uma invenção de Mack. Os textos que compõem o Novo Testamento foram coletados de acordo com o interesse de uma forma particular de congregação cristã que se formou aos poucos, entre o segundo e o quarto séculos. Ao chamar essa forma de cristianismo de "centrista", Mack quer dizer que "ela se posiciona entre as formas gnósticas de cristianismo, por um lado, e formas radicais de comunidades Paulinas e espiritualistas, por outro. Foi o cristianismo centrista que se tornou a religião do Império sob Constantino, reuniu os textos que hoje conhecemos como o Novo Testamento e os juntou às escrituras judaicas para formar a Bíblia cristã" (1996, p. 6).

10 A esse respeito, o historiador da religião John Crossan foi mais longe, a ponto de sugerir que Paulo foi mais importante, tanto de um ponto de vista histórico como teológico, no século VI do que no primeiro (ver Crossan, 1999, p. xxi).

11 Ver a esse respeito J. Crossan (1999, especialmente o capítulo 2).

12 A preocupação em apresentar o cristianismo como uma religião antiga permaneceu extremamente viva até pelo menos o século IV. Isto fica evidente se lermos a História eclesiástica, de Eusébio, bispo da Cesaréia. Assim, o livro 1, capítulo 4:1, diz: "Mas para que ninguém suponha que sua [a de Jesus] doutrina seja nova e estranha, como se tivesse sido elaborada por um homem de origem recente, e em nada diferente dos demais, passemos a considerar brevemente essa questão também"; e, o parágrafo 4 deste mesmo capítulo afirma: "Mas se somos evidentemente novos e se este nome de cristãos, novo na verdade, é conhecido somente há pouco tempo por todas as nações, nosso modo de vida e nosso comportamento, com nossas doutrinas religiosas, não foram recentemente inventados por nós, mas desde a criação primordial do homem, por assim dizer, foram estabelecidos pelo entendimento natural dos hebreus, os divinamente favorecidos de outrora" (Eusébio, Church history, versão eletrônica, tradução livre).

13 Justino, o mártir, Apologia 1:63, apud Mack (1996, p. 270).

14 O verso de Schiller é "Quando a alma fala, ai de nós!, não é mais a alma que fala" (ver Munz, 1999, p. 20).

15 Talvez o leitor não saiba que na Bíblia hebraica o livro de Malaquias situa-se no meio, e o livro de Crônicas é o último, por ser o mais tardio. Após a Bíblia hebraica ter sido transformada no "Antigo Testamento" da Bíblia cristã, o livro de Malaquias tornou-se o último, em razão do que diz no capítulo 3, parágrafo 1: "Eis que enviarei o meu mensageiro para que prepare um caminho diante de mim".

16 Os outros dois momentos são a profecia hebraica, por ter eliminado a magia, e o milagre de Pentecostes, por ter promovido a fraternização no espírito cristão.

17 Schluchter expôs esta tese da seguinte maneira: "Jesus iniciou uma revolução de convicção, de valores últimos, a qual conduziu a uma religiosidade da fé. Nem a subordinação da 'lei sagrada' à 'sagrada convicção', a penetração dos conteúdos da Torá e da profecia ética [hebraica] pelo mandamento do amor, nem a expectativa da segunda vinda de Jesus, combinada com uma moralidade rudimentar do ressentimento, traduz o caráter radical dessa transformação. Esta se expressa muito mais em uma atitude interna nãoracional de 'confiança ilimitada em Deus'. Jesus buscava uma fé caracterizada pela convicção supra-intelectual. Sua mensagem produziu a unificação, a simplificação e a internalização do modo religioso de vida. Ela também substituiu o virtuoso da lei pelo virtuoso da fé, produzindo, 
assim, uma nova forma de aristocracia sagrada" (1989, p. 210). Este excerto levará o leitor desavisado a concluir que o estabelecimento de uma ortodoxia cristã foi algo que se estabeleceu de forma muito fácil.

18 "[...] a religião judaica tornou-se notavelmente uma religião de retribuição. As virtudes demandadas por Deus são praticadas apenas para obter compensação" (Weber, 1965 [1922], p. 112).

19 A bem da verdade, Weber sabia disso. Em The sociology of religion, ele menciona, de passagem, "que a espera dos judeus por um governante autoritário, na pessoa do Messias, foi mantida até, pelo menos, a destruição do Templo por [Tito]" (p. 228). Weber só não se perguntou que tipo de esperança foi mantida pelos fariseus após tal destruição.

20 Na verdade, desde a destruição do segundo templo, em 70 d.C., não há outro judaísmo além do farisaico.

21 Este livro foi recentemente traduzido para o português, ver Josefo (2006).

22 A bem da verdade, a tese do povo pária é de valor duvidoso mesmo em relação à Idade Média. O scholar Ephraim Shmueli deixou isto claro: "Até o século XIV, os judeus eram aceitos nas guildas dos comerciantes e dos artesãos [...]. Apenas no período da peste negra, com as revoltas plebéias contra os patrícios, as guildas de ofício tornaram-se poderosas na Alemanha, excluindo os judeus, embora não totalmente nem em todo lugar. Em muitas cidades da Alemanha os judeus eram burgueses e empregavam cristãos. Eles administravam seus próprios negócios por intermédio de instituições autônomas no âmbito da comunidade citadina. Esses fatos não são certamente evidência de uma situação de pária" (Shmueli, 1968, p. 191).

23 De fato, esta é uma interpretação generosa. Um teólogo judeu como Leo Baeck não se surpreenderia com o fato de Paulo ter ignorado o conceito judaico de arrependimento por uma razão bastante diferente. Para Baeck, não haveria lugar para o arrependimento no pensamento de Paulo porque a doutrina deste último postulava um "homem completo" (finished man). Ela supunha que quando um homem "recebe" Cristo ele se completa, nada mais havendo para aprender ou do que se arrepender (ver Baeck, 1958, especialmente o capítulo intitulado "Romantic religion").

24 Devo esta informação a um texto de autoria anônima, intitulado Christian Talmud, disponível no site http://www.geocities.com/athens/parthe- non/2787/ixcnine.html. Embora a autoria seja anônima, o Autor oferece a fonte, a obra do rabino alemão Jacob Emden (1697-1776), e a informação em questão é consistente com as informações obtidas na Encyclopaedia judaica, verbete: "Jewish Christian Sects".

\section{BIBLIOGRAFIA}

BAECK, Leo. (1958), Judaism and Christianity. Nova York, The Jewish Publications Society of America.

CAUSSE, Antonin. (1937), Du groupe ethnique à la communauté religieusse: le problème sociologique de la religion d'Israel. Paris, Libraire Felix Alcan.

CROSSAN, J. D. (1999), The birth of Christianity. Nova York, HarperCollins.

FREDRIKSEN, Paula \& LIEU, Judith. (2004), "Christian theology and Judaism", in G. R. Evans (ed.), The first Christian theologians: an introduction to theology in early church, Londres, Blackwell.

GASTON, L. (1987), Paul and the Torah. Vancouver, University of British Columbia Press.

GRAF, Friedrich W. (1993), "The German theological sources and Protestant church politics", in H. Lehman e G. Roth (eds.), Weber's Protestant ethic, origins, evidence, contexts, Cambridge, Cambridge University Press.

JOSEFO, Flávio. (2006), Antiguidades dos Judeus contra Apião. Curitiba, Juruá.

JUSTINO. (1995), Justino de Roma (Apologias I e II. Diálogo com Trifão). São Paulo, Paulus.

KEENER, Criag S. (2005), Comentário Bíblico Atos - Novo Testamento. Belo Horizonte, Atos.

MACK, Burton. (1996), Who wrote the New Testament? The making of the Christian myth. San Francisco, Harper.

MUNZ, Peter. (1999), Critique of impure reason. Londres, Praeger. 
NEUSNER, J. (1991), Jews and Christians: the myth of a common tradition. Londres, SCM Press.

NIREMBERG, David. (2003), "The birth of the pariah: Jews, Christian dualism, and social science”. Social Research, 70 (1): 201-236.

RUETHER, R. (1974), Faith and fratricide: the theological roots of anti-semitism. Minneapolis, The Seabury Press.

SCHLUCHTER, W. (1981), The rise of western rationalism: Max Weber's developmental history. Berkeley, University of California Press.

(1989), Rationalism, religion and domination: a Weberian perspective. Berkeley, University of Columbia Press.

SHMUELI, E. (1968), “The 'pariah-people' and its 'charismatic leadership': a revaluation of Max Weber's 'Ancient Judaism”. American Academy for Jewish Research, Proceedings, 36: 167-247.

WEBB, Joseph M. (1998), "In the midst of another revolution: from the Old Testament to the first Testament". Trabalho apresentado no Annual Meeting of the Academy of Homiletics, Emmanuel College, Knox College, Toronto School of Theology, Dec. 3-5, pp. 1-11 (versão em pdf).

WEBER, Max. (1952), Ancient Judaism. Glencoe, Free Press.

(1960), The religion of India. Nova York, Free Press.

(1965 [1922]), The sociology of religion. Londres, Methuen.

(1993), General economic bistory. Londres, Transactions Publisher. 
A SOCIOLOGIA DA RELIGIÃO COMO RECAPITULAÇÃO DA TEOLOGIA CRISTÃ: WEBER E AS RAÍZES PROFÉTICAS DO RACIONALISMO OCIDENTAL

\section{Renan Springer de Freitas}

Palavras-chave: Sociologia da religião; Racionalismo ocidental; Profecia hebraica; Teologia cristã.

Desde os escritos seminais de Max Weber, a sociologia da religião tem retratado a profecia hebraica como a própria matriz do racionalismo ocidental, ao mesmo tempo em que lhe tem atribuído a promessa de um futuro no qual Israel prevaleceria sobre todas as outras nações. Após a experiência do exílio babilônico, essa promessa teria transformado os judeus em um "povo-pária", auto-segregado, ritualista, legalista, orientado por uma ética dual e, como tal, incapaz de conferir uma dinâmica universalista ao monoteísmo ético peculiar a seu próprio Livro sagrado. A profecia hebraica teria, nessa perspectiva, dado início a um processo evolutivo que somente o Novo Testamento, com sua doutrina da salvação universal, via sacrifício do Redentor, teria sido capaz de levar adiante. Argumenta-se que tal linha de raciocínio, que se encontra na base de todo o empenho, de matriz weberiana, em explicar a evolução da ética ocidental, se desenvolveu no interior de um arcabouço cuja natureza é teológica; mais precisamente, nos marcos da "teologia cristã da superação", assim chamada por postular que o Novo Testamento superou o judaísmo ao universalizar o acesso à graça divina que este último havia restringido a um pretenso "povo escolhido".

\section{THE SOCIOLOGY OF RELIGION AS A REVIEW OF THE CHRISTIAN THEOLOGY: WEBER AND THE PROPHETIC ROOTS OF OCCIDEN- TAL RATIONALISM}

Renan Springer de Freitas

Keywords: Sociology of religion; Occidental rationalism; Hebraic prophecy; Christian theology.

Since the seminal writings of Max Weber, the sociology of religion has pictured the Hebraic prophecy as the very matrix of the occidental rationalism, while attributing to it the promise of a future in which Israel would prevail over all other nations. After the experience of the Babylonic exile, such promise has transformed the Jews in a "pariah-peoples," selfsegregated, ritualistic, le- galist, oriented by some dual ethics and, as a result, unable to confer a universalistic dynamics to the ethical monotheism peculiar to its own sacred Book. The Hebraic prophecy would have, in this perspective, begun the evolutive process that only the New Covenant, with its universal salvation doctrine via the sacrifice of The Redeemer, would have been able to carry out. It is argued that such reasoning, found in the basis of all the effort of Weber to explain the evolution of the occidental ethics, has developed within some theological framing. It can be seen more precisely in the markings of the "Christian theology of overcoming," which postulates that the New Covenant has superseded Judaism by making universal the access to the divine grace the latter had restricted to a pretense "chosen peoples."
LA SOCIOLOGIE DE LA RELIGION EN TANT QUE RECAPITULATION DE LA THÉOLOGIE CHRÉTIENNE: WEBER ET LES RACINES PROPHÉTIQUES DU RATIONALISME OCCIDENTAL

Renan Springer de Freitas

Mots-clés: Sociologie de la religion; Racionalisme occidental; Prophétie hébraïque; Théologie chrétienne.

Depuis les écrits séminaux de Max Weber, la sociologie de la religion traite la prophétie hébraïque comme la propre matrice du rationalisme occidental, en même temps qu'elle lui attribue la promesse d'un futur dans lequel Israël prévaudrait sur toutes les autrres nations. Suite à l'exil babylonien, cette promesse aurait transformé les juifs en un "peupleparia”, auto-ségrégué, ritualiste, légaliste, orienté par una éthique dualiste et, en tant que tel, incapable de conférer une dynamique universaliste au monothéisme éthique propre à son Livre sacré. La prophétie hébraïque aurait, suivant cette perspective, été à l'origine d'un processus évolutif qui n'aurait été mené à bon terme que par le Nouveau Testament, avec sa doctrine de salut universel par le sacrifice du Rédempteur. Nous défendons qu'une telle ligne de pensée qui se trouve à la base de tout l'effort, de matrice webérienne - s'est, en expliquant l'évolution de l'éthique occidentale, développée à l'intérieur d'une structure de nature théologique et, plus précisement, suivant les indicateurs de la "théologie chrétienne de surpassement", qui se nomme ainsi par le fait de soutenir que le Nouveau Testament a supplanté le judaïsme en mondialisant l'accès à la grâce divine que ce dernier avait limité à un soit-disant "peuple élu". 